\title{
Effects of a Supplement Containing Trans-10, Cis-12 Conjugated Linoleic Acid on Bioenergetic and Milk Production Parameters in Grazing Dairy Cows Offered Ad Libitum or Restricted Pasture
}

\author{
J. K. Kay, ${ }^{\star} \dagger$ T. R. Mackle, ${ }^{\star}$ D. E. Bauman, $\ddagger$ N. A. Thomson, ${ }^{\star}$ and L. H. Baumgard ${ }^{1}$ \\ *Dexcel, Ltd., Hamilton, New Zealand \\ †Department of Animal Sciences, The University of Arizona, Tucson 85721 \\ ‡Department of Animal Science, Cornell University, Ithaca, NY 14853
}

\begin{abstract}
Conjugated linoleic acid (CLA) reduces milk fat synthesis in grazing dairy cows and may improve calculated net energy balance (EBAL). Study objectives were to determine whether CLA-induced milk fat depression could be utilized during times of feed restriction to improve bioenergetic and milk production parameters. Twelve multiparous rumen-fistulated Holstein cows (204 $\pm 7 \mathrm{~d}$ in milk) were offered ad libitum (AL) or restricted $(\mathrm{R})$ pasture and abomasally infused twice daily with 0 (control) or $50 \mathrm{~g} / \mathrm{d}$ of CLA (CLA; mixed isomers) in a 2-period crossover design. Treatment periods lasted $10 \mathrm{~d}$ and were separated by a 10-d washout period. Milk and plasma samples were averaged from d 9 and 10, and EBAL was calculated from d 6 to 10 of the infusion period. Pasture restriction reduced the yield of milk (3.9 kg/d) and milk components. The CLA treatment reduced milk fat yield by 44 and $46 \%$ in $\mathrm{AL}$ and $R$, respectively. There was no effect of CLA on milk yield or milk lactose content or yield in either feeding regimen; however, CLA increased the milk protein content and yield by 7 and $6 \%$ and by 5 and $8 \%$, in AL and $R$, respectively. The CLA-induced changes to milk fat and protein doubled the protein:fat ratio in both $\mathrm{AL}$ and R. Calculated EBAL improved following the CLA infusion ( -0.44 vs. 2.68 and 0.38 vs. $3.29 \mathrm{Mcal} / \mathrm{d}$ for AL and R, respectively); however, CLA did not alter plasma bioenergetic markers. Data indicate that during short periods of nutrient limitation, supplemental CLA may be an alternative management tool to enhance protein synthesis and improve the milk protein:fat ratio and calculated EBAL in cows grazing pasture. Further studies are required to determine whether CLA is effective at improving bioenergetic and production parameters during more severe or longer term nutrient restriction. Key words: conjugated linoleic acid, pasture, milk fat, energy balance
\end{abstract}

Received June 5, 2006.

Accepted September 13, 2006.

${ }^{1}$ Corresponding author: baumgard@ag.arizona.edu

\section{INTRODUCTION}

Abomasally infusing conjugated linoleic acid (CLA) and supplementing rumen-inert CLA reduces milk fat synthesis in cows consuming pasture (Mackle et al., 2003; Back and Lopez-Villalobos, 2004; Kay et al., 2006) or a TMR (Loor and Herbein, 1998; Chouinard et al., 1999; Giesy et al., 2002; Perfield et al., 2002) and can improve calculated net energy balance (EBAL) parameters immediately postpartum (Moore et al., 2004; Shingfield et al., 2004; Kay et al., 2006; Odens et al., 2007) and during heat stress (Moore et al., 2005). In a pasture-based dairy system (as is predominant in New Zealand), another episode of transitory nutritional stress can occur during adverse weather conditions that reduce forage growth, forage quality, or both. During these periods of reduced nutrient availability, animals typically enter into a negative EBAL (NEBAL) as homeorhetic controls alter tissue metabolism in an attempt to support the dominant physiological condition (i.e., lactation; Bauman and Currie, 1980). During this adaptation, energy and nutrients are partitioned to the mammary gland at the expense of extramammary tissue, and this may result in tissue loss, metabolic disorders, and reproductive dysfunction (Collier et al., 2005). However, as the severity of NEBAL increases, homeostatic survival systems overwhelm the homeorhetic drive for lactation; consequently, milk and milk component production decrease in an attempt to minimize the adverse effects of NEBAL (Collier et al., 2005). Previous management strategies to improve or alleviate NEBAL and maintain animal condition and milk production during feed restriction traditionally involve increasing the dietary energy content (via dietary supplements) or decreasing energy expenditure/output (via reducing the milking frequency). An alternative approach is to reduce milk energy secretion by decreasing milk fat production.

In addition to alleviating the calculated NEBAL, CLA-induced milk fat depression (MFD) has allowed for increased milk and milk protein yields in grazing dairy cows (Mackle et al., 2003) and early lactating 
cows (Back and Lopez-Villalobos, 2004; Shingfield et al., 2004; Kay et al., 2006; Odens et al., 2007), 2 situations in which energy is probably limiting milk synthesis (Baumgard et al., 2006). Currently, the New Zealand milk payment system encourages an increased milk protein:fat ratio, and Back and Lopez-Villalobos (2004) used a simulation model to calculate dairy product yields and values; they reported enhanced milk value ( $\$ 0.27 / \mathrm{kg}$ of milk solids) from cows fed CLA for $16 \mathrm{wk}$ compared with controls. Thus, there may be economic incentives for producing milk with an increased protein:fat ratio during periods of nutrient restriction. The objectives of the present study were to determine whether abomasal CLA infusion would inhibit milk fat synthesis to a similar extent in nutrient-restricted and ad libitum grazing dairy cows, and whether the subsequent enhanced energetic state would allow for improved production and bioenergetic variables.

\section{MATERIALS AND METHODS}

\section{Experimental Design, Animals, and Treatments}

All procedures involving animals were approved by the Ruakura Animal Ethics Committee (Hamilton, New Zealand). Twelve multiparous, lactating HolsteinFriesian dairy cows (204 \pm 7 DIM) grazing a pasture allowance of $\sim 35 \mathrm{~kg}$ of $\mathrm{DM} / \mathrm{d}$ were allocated to 1 of 2 pasture levels; ad libitum (AL; $42 \pm 6.3 \mathrm{~kg}$ of DM/d) or restricted $(\mathbf{R} ; 22 \pm 8.5 \mathrm{~kg}$ of $\mathrm{DM} / \mathrm{d})$ pasture allowance, balanced for milk production, milk composition, and parity. Cows were maintained on their designated pasture allowance throughout the entire experiment and were abomasally infused with 0 (control) or $50 \mathrm{~g} / \mathrm{d}$ of a free fatty acid CLA mixture (CLA; Natural Lipids, Hovdebygda, Norway) in a 2-period crossover design. Abomasal CLA infusions began $4 \mathrm{~d}$ after dietary allocation, and the 10-d treatment periods were separated by a $10-d$ washout interval. Daily infusate volumes were loaded into two $60-\mathrm{mL}$ syringes $(25 \mathrm{~mL} /$ syringe) and infused prior to a.m. and p.m. milkings via polyvinyl chloride tubing (Nalgene 180 PVC; $0.47 \mathrm{~cm}$ i.d. $\times 0.78$ cm o.d.; Nalge Co., Rochester, NY), which extended through the rumen fistula and sulcus omasi into the abomasum, where it was secured by a $10-\mathrm{cm}$ rubber flange (Mackle et al., 2003). To reduce viscosity and ensure that all lipid was infused, the infusate was warmed to $\sim 35^{\circ} \mathrm{C}$ prior to dosing and chased with 180 $\mathrm{mL}$ of warm water. Control cows received an extra 50 $\mathrm{mL}$ of warm water in place of the CLA infusate. The fatty acid composition of the CLA supplement is presented in Table 1. The CLA treatment provided $9 \mathrm{~g}$ of trans-10, cis-12 CLA and $31 \mathrm{~g}$ of total CLA isomers daily. All cows were rotationally grazed and offered fresh pasture twice daily. Different pasture allowances
Table 1. Fatty acid composition of conjugated linoleic acid ${ }^{1}$ (CLA) infusate

\begin{tabular}{lcc}
\hline Fatty acid & $\begin{array}{c}\text { \% of total } \\
\text { fatty acids }\end{array}$ & $\begin{array}{l}\text { \% of total } \\
\text { CLA }\end{array}$ \\
\hline $16: 0$ & 4.2 & \\
$18: 0$ & 2.2 & \\
$18: 1$ cis-9 & 21.1 & \\
18:2 cis-9, cis-12 & 6.5 & $(100.0)$ \\
CLA (total) & $(61.6)$ & 14.9 \\
CLA trans-8, cis-10 & 9.2 & 24.2 \\
CLA cis-9, trans-11 & 14.9 & 30.0 \\
CLA trans-10, cis-12 & 18.5 & 17.1 \\
CLA cis-11, trans-13 & 10.5 & 13.8 \\
Other CLA & 8.5 & \\
Unknown & & \\
\hline
\end{tabular}

${ }^{1}$ CLA-60 (Natural Lipids Ltd., Novdebygda, Norway).

${ }^{2}$ Represents unidentified chromatographic peaks.

were based on previous data (Mackle et al., 1999; Auldist et al., 2000) in an attempt to reduce milk yield by $\sim 25 \%$ with pasture restriction. Pasture allocations were offered by multiplying pregrazing pasture mass per square meter by the desired allowance per cow $(\mathrm{kg} / \mathrm{d})$ by the number of cows in each dietary group $(n=6$; Roche et al., 2005). All cows grazed within the same paddock, and different-sized areas and allocations were separated by double-stranded electric fences. Pregrazing herbage mass for both treatment groups approximated $\sim 3,100 \mathrm{~kg}$ of $\mathrm{DM} / \mathrm{ha}$, and postgrazing residual mass was $\sim 2,100 \mathrm{~kg}$ of DM/ha and $1,600 \mathrm{~kg}$ of DM/ha in $\mathrm{AL}$ and $\mathrm{R}$, respectively.

\section{Pasture Analysis and DMI}

Individual DMI was estimated during the last $5 \mathrm{~d}$ of each infusion period using the $n$-alkane technique (Mayes et al., 1986), as modified and described by Roche et al. (2005). Throughout the experiment, representative pasture samples were collected daily by handplucking pasture to the predicted grazing height from paddocks immediately prior to grazing. Samples were bulked every $5 \mathrm{~d}$, and triplicate samples were either frozen immediately $\left(-20^{\circ} \mathrm{C}\right)$ for fatty acid analysis, dried at $100^{\circ} \mathrm{C}$ for $\mathrm{DM}$ analysis, or dried at $60^{\circ} \mathrm{C}$ for nutrient composition analysis. Samples for nutrient composition were dried for $48 \mathrm{~h}$, ground to pass through a $1.0-\mathrm{mm}$ sieve (Christy Lab Mill, Suffolk, UK), and analyzed for $\mathrm{CP}, \mathrm{NDF}, \mathrm{ADF}$, soluble sugars, ash, and OM digestibility by near-infrared spectroscopy (Corson et al., 1999). Metabolizable energy was derived directly from predicted OM digestibility on the basis of an in vitro cellulase digestibility assay (Roughan and Hollan, 1977; Dowman and Collins, 1982), which had been calibrated against in vivo standards (Corson et al., 1999).

Frozen feed samples for fatty acid analysis were freeze-dried (model 0610; Cuddon Ltd., Blenheim, NZ), 
Table 2. Nutrient and fatty acid composition of pasture ${ }^{1}$

\begin{tabular}{lr}
\hline Item & Amount \\
\hline Nutrient composition, \% of $\mathrm{DM}^{2}$ & \\
CP & 16.2 \\
Total fatty acids & 4.1 \\
Ash & 10.4 \\
NDF & 49.8 \\
ADF & 25.4 \\
Soluble sugars & 9.1 \\
ME, Mcal/kg of DM & 2.5 \\
Fatty acid composition, \% of total fatty acids & \\
14:0 & 0.8 \\
16:0 0 cis-9 & 15.4 \\
18:0 & 1.8 \\
$18: 1$ cis-9 & 6.7 \\
18:2 cis-9, cis-12 & 3.1 \\
18:3 cis-9, cis-12, cis-15 & 12.5 \\
Unknown & 48.9 \\
\hline
\end{tabular}

${ }^{1}$ Data represent the average from the entire experimental period.

${ }^{2}$ Dietary DM averaged $16.7 \%$.

${ }^{3}$ Represents unidentified chromatographic peaks.

and ground to pass through a 0.5 -mm sieve (Christy Lab Mill). Pasture lipids were extracted and methylated according to the one-step method of Garces and Mancha (1993) as outlined in Kay et al. (2004). Fatty acid analysis was performed on a Hewlett-Packard 5890 Series II gas chromatograph equipped with a 30-m RTX-2330 column $(30 \mathrm{~m} \times 0.32 \mathrm{~mm}$ i.d. and $0.2 \mu \mathrm{m}$ film thickness; Restek Corp., Bellefonte, PA), and gas chromatographic conditions and fatty acid identification parameters were as previously described (Kay et al., 2004).

The pasture offered consisted of $75 \%$ perennial ryegrass (Lolium perenne L.), $4 \%$ white clover (Trifolium repens L.), $2 \%$ weeds and other grasses (Dactylus glomerata, Holcus lanatus, and some Poa species) and 19\% dead material on a DM basis. The pasture nutrient profile and fatty acid composition are presented in Table 2 .

\section{Milk Sampling and Analysis}

Cows were milked twice daily at 0600 and $1700 \mathrm{~h}$. Milk yield was recorded at each milking, and samples were collected for analysis of fat, true protein, and lactose using an infrared milk analyzer (FT120; Foss Electric, Hillerød, Denmark); and urea (urease method; Talke and Schuberts, 1965) and citrate using spectrophotometric detection (Shimadzu UV-160A; Shimadzu Corporation, Kyoto, Japan) based on the method of Dagley (1974). Total $\mathrm{N}(\mathbf{T N})$ and $\mathrm{N}$ fractions were determined using macro-Kjeldahl techniques (AOAC, 2000). Milk NPN consisted of $\mathrm{N}$ that was soluble in $12 \%$ TCA. Noncasein N (NCN) was determined according to Inter- national Dairy Federation procedures (IDF, 1964); CN was precipitated at $\mathrm{pH} 4.6$ and removed by filtration, leaving the filtrate for $\mathrm{N}$ analysis. From these $\mathrm{N}$ fractions, $\mathrm{CP}(\mathrm{TN} \times 6.38)$ and $\mathrm{CN}[(\mathrm{TN}-\mathrm{NCN}) \times 6.38]$ were calculated. Milk NCN and NPN were multiplied by 6.38 to convert to protein equivalents and allow comparison with other protein fractions.

On the last $2 \mathrm{~d}$ of the infusion periods ( $\mathrm{d} 9$ and 10), milk fat was extracted from the composite samples using a modified Röse-Gottlieb technique as previously described (Kay et al., 2006) and stored at $-20^{\circ} \mathrm{C}$ for fatty acid analysis. Fatty acids were methylated using sodium methoxide as described by MacGibbon (1988), and fatty acid methyl esters were quantified by GLC performed on a Shimadzu 17A gas chromatograph equipped with a flame ionization detector, autosampler, and autoinjector (Shimadzu Corporation, Kyoto, Japan). A $120-\mathrm{m}$ BPX-70 column $(120 \mathrm{~m} \times 0.25 \mathrm{~mm}$ i.d. and $0.25 \mu \mathrm{m}$ film thickness; SGE, Ringwood, Victoria, Australia) was used, and gas chromatographic conditions and fatty acid identification procedures were as described by Kay et al. (2004).

\section{Blood Sampling and Analysis}

One evacuated blood tube containing a sodium heparin pellet (100 IU of sodium heparin/mL of blood) to prevent coagulation was collected from each cow by coccygeal venipuncture after both milkings on $d 9$ and 10 of the infusion periods. Plasma was harvested following centrifugation $\left(1,120 \times \mathrm{g}, 10 \mathrm{~min}\right.$ at $\left.4^{\circ} \mathrm{C}\right)$ and analyzed for NEFA, BHBA, glucose, urea, and insulin. The NEFA (colorimetric method), BHBA (BHBA dehydrogenase assay), glucose (hexokinase method), and urea (urease method) analyses were performed on a Hitachi 717 analyzer (Roche, Basel, Switzerland) at $30^{\circ} \mathrm{C}$ by Alpha Scientific (Hamilton, NZ). The inter- and intraassay coefficient of variation was $<2 \%$ for all assays. Insulin was measured in duplicate by a double-antibody RIA with an inter- and intraassay coefficient of variation of $<4 \%$ (Hales and Randle, 1963).

\section{Calculations}

Net energy balance was calculated during the last 5 d of infusion period (d 6 to 10) using the following equation:

$$
\mathrm{EBAL}=\text { net energy intake }-\left(\mathrm{NE}_{\mathrm{M}}+\mathrm{NE}_{\mathrm{L}}\right) .
$$

Net energy intake was calculated by multiplying the $n$-alkane-estimated DMI by the net energy of pasture (1.54 Mcal $/ \mathrm{kg}$ of DM) plus the net energy value of the CLA supplement (5.02 Mcal/kg of DM; NRC, 2001). The 
KAY ET AL.

Table 3. Effect of abomasal infusion of 0 or $50 \mathrm{~g} / \mathrm{d}$ of conjugated linoleic acid (CLA) for $10 \mathrm{~d}$ on production parameters in cows offered ad libitum or restricted pasture ${ }^{1}$

\begin{tabular}{|c|c|c|c|c|c|c|c|c|}
\hline \multirow[b]{2}{*}{ Variable } & \multicolumn{2}{|c|}{$\begin{array}{l}\text { Ad libitum } \\
\text { allowance }\end{array}$} & \multicolumn{2}{|c|}{$\begin{array}{l}\text { Restricted } \\
\text { allowance }\end{array}$} & \multirow[b]{2}{*}{ SEM } & \multicolumn{3}{|c|}{$P^{2}$} \\
\hline & Control & CLA & Control & CLA & & CLA & A & $\mathrm{CLA} \times \mathrm{A}$ \\
\hline DMI, kg/d & 13.4 & 13.4 & 11.6 & 12.2 & 0.52 & 0.56 & 0.01 & 0.51 \\
\hline $\mathrm{EBAL},{ }^{3} \mathrm{Mcal} / \mathrm{d}$ & -0.44 & 2.68 & 0.38 & 3.29 & 0.93 & $<0.01$ & 0.46 & 0.91 \\
\hline Milk yield, kg/d & 15.7 & 15.4 & 11.5 & 11.9 & 0.7 & 0.86 & $<0.01$ & 0.41 \\
\hline \multicolumn{9}{|l|}{ Fat } \\
\hline$\%$ & 4.44 & 2.52 & 4.94 & 2.57 & 0.13 & $<0.01$ & 0.04 & 0.09 \\
\hline $\mathrm{kg} / \mathrm{d}$ & 0.69 & 0.39 & 0.56 & 0.30 & 0.02 & $<0.01$ & $<0.01$ & 0.21 \\
\hline \multicolumn{9}{|l|}{ Protein } \\
\hline & 3.31 & 3.55 & 3.20 & 3.36 & 0.05 & $<0.01$ & 0.04 & 0.56 \\
\hline $\mathrm{kg} / \mathrm{d}$ & 0.52 & 0.55 & 0.37 & 0.40 & 0.01 & 0.05 & $<0.01$ & 0.67 \\
\hline \multicolumn{9}{|l|}{ Lactose } \\
\hline & 4.73 & 4.65 & 4.76 & 4.70 & 0.07 & 0.31 & 0.56 & 0.92 \\
\hline $\mathrm{kg} / \mathrm{d}$ & 0.74 & 0.72 & 0.55 & 0.57 & 0.04 & 0.69 & $<0.01$ & 0.44 \\
\hline \multicolumn{9}{|l|}{ Total solids } \\
\hline & 12.48 & 10.72 & 12.90 & 10.6 & 0.17 & $<0.01$ & 0.38 & 0.12 \\
\hline $\mathrm{kg} / \mathrm{d}$ & 1.96 & 1.65 & 1.48 & 1.27 & 0.08 & $<0.01$ & $<0.01$ & 0.39 \\
\hline Protein:fat & 0.75 & 1.41 & 0.65 & 1.31 & 0.03 & $<0.01$ & $<0.01$ & 0.86 \\
\hline Citrate, $\mathrm{mg} / \mathrm{mL}$ & 1.44 & 1.66 & 1.25 & 1.61 & 0.11 & 0.02 & 0.29 & 0.55 \\
\hline Urea, $\mathrm{m} M$ & 6.65 & 6.28 & 6.13 & 6.21 & 0.19 & 0.46 & 0.12 & 0.25 \\
\hline
\end{tabular}

${ }^{1}$ Data represent average from d 9 and 10 of infusion periods. Ad libitum allowance: daily pasture allowance of $42 \pm 6.3 \mathrm{~kg}$ of DM/cow. Restricted allowance: daily pasture allowance of $22 \pm 8.5 \mathrm{~kg}$ of DM/cow. Control treatment: abomasal infusion of $0 \mathrm{~g} / \mathrm{d}$ of CLA. CLA treatment: abomasal infusion of $50 \mathrm{~g} / \mathrm{d}$ of CLA.

${ }^{2}$ Significance of effects for CLA dose (CLA), pasture allowance (A), and the interaction between CLA dose and pasture allowance $(\mathrm{CLA} \times \mathrm{A})$.

${ }^{3}$ Mean net energy balance $=$ net energy intake $-($ net energy for maintenance + net energy for lactation $)$; calculated from d 6 to 10 of the infusion periods.

$\mathrm{NE}_{\mathrm{M}}$ for pasture-fed cows was calculated according to NRC (2001) guidelines using the following equation:

$$
\mathrm{NE}_{\mathrm{M}}=0.06 \times \mathrm{BW}^{0.75}
$$

(Holmes et al., 2002). The $\mathrm{NE}_{\mathrm{L}}$ was calculated according to NRC (2001) guidelines by the following equation:

$$
\begin{gathered}
\mathrm{NE}_{\mathrm{L}}=[(0.0929 \times \text { fat } \%)+(0.0547 \times \mathrm{CP} \%) \\
+(0.0395 \times \text { lactose } \%)] \times \text { milk production }(\mathrm{kg}) .
\end{gathered}
$$

\section{Statistical Analysis}

Milk and plasma data from d 9 and 10 of each infusion period were analyzed by repeated measures using the PROC MIXED procedure of SAS (SAS Institute, 2001) with an autoregressive covariance structure and day of infusion as the repeated effect. The model contained period, day of infusion, pasture allowance, CLA dose, and all possible interactions. The DMI and EBAL were analyzed using the PROC MIXED procedure of SAS (SAS Institute, 2001). The model contained period, pasture allowance, CLA dose, and all possible interactions. Standard errors of the mean are reported and differ- ences were considered significant when $P<0.05$ unless otherwise stated.

\section{RESULTS}

Pasture restriction reduced $(P<0.01)$ DMI $(1.5 \mathrm{~kg} /$ d) and the yield of milk and milk components $(\sim 25 \%)$ but did not affect milk metabolite levels (Table 3). There was a small increase in milk fat content $(P<0.05 ; 8 \%)$ and decrease in milk protein content $(P<0.05 ; 4 \%)$ with pasture restriction (Table 3 ). Conjugated linoleic acidinduced MFD (based on milk fat content) became significant by d 2 of infusion $(P<0.01 ; 15 \%)$ and reached a nadir by d 4 (44\%; Figure 1A). By 5 d postinfusion, the milk fat content had returned to preinfusion levels (Figure 1A). By d 9 and 10, the CLA infusion had reduced the milk fat content and yield by 43 and $44 \%$, and by 48 and $46 \%$ in the AL and R groups, respectively (Table 3; Figure 1A and 1B). There was no CLA effect on milk yield or on milk lactose content or yield; however, it increased both the milk protein content and yield $(P<$ 0.05 ) by 7 and $6 \%$ and by 5 and $8 \%$ for AL and R, respectively. Within the milk protein constituents, CLA increased $(P<0.05)$ true protein, $\mathrm{CP}, \mathrm{CN}, \mathrm{NPN}$, and NCN; however, whey protein was not affected (Table 
A
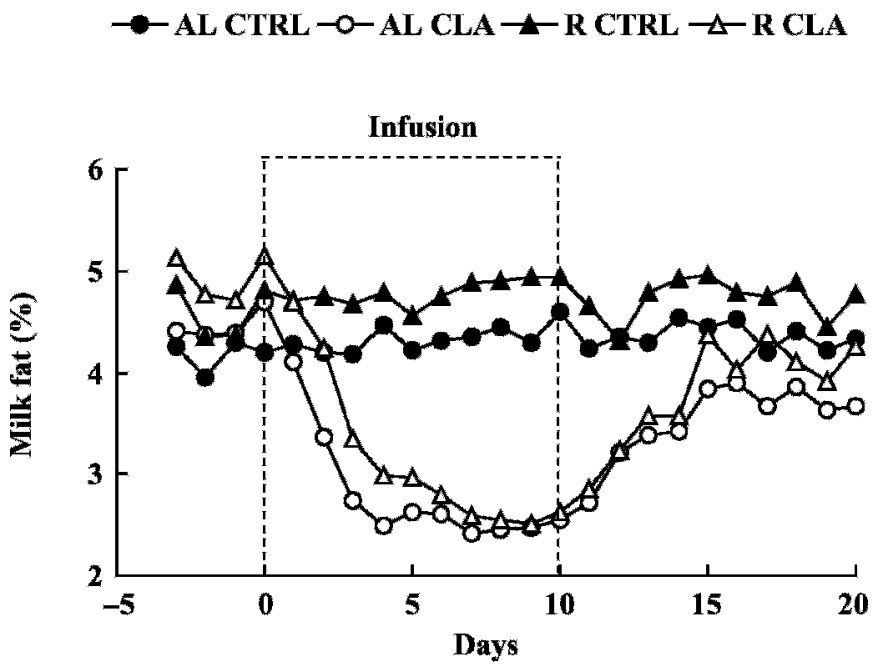

B
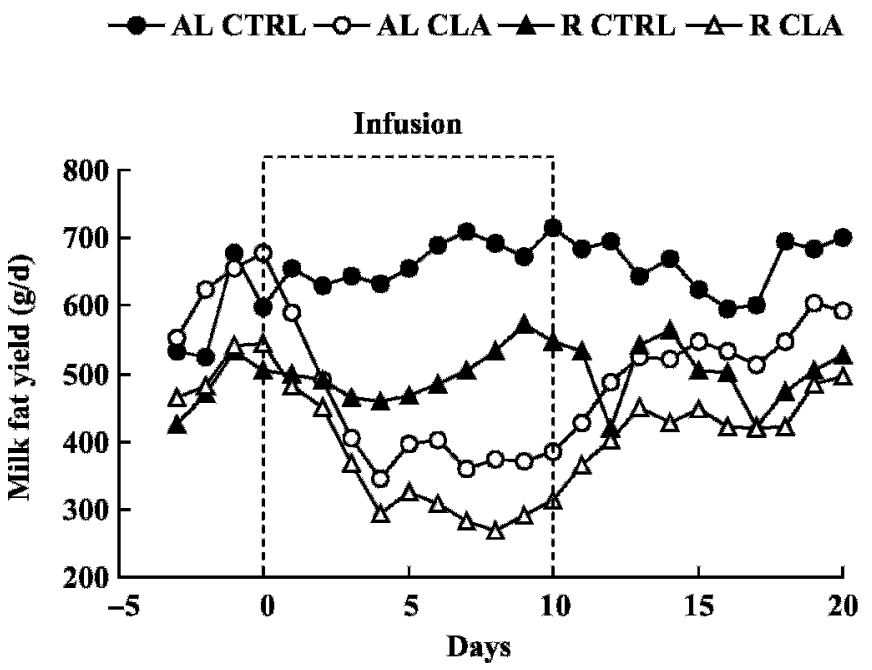

Figure 1. Temporal pattern of (A) milk fat content (\%) and (B) milk fat yield $(\mathrm{g} / \mathrm{d})$. Treatments were ad libitum (AL) or restricted (R) pasture allowance with abomasal infusion of 0 (CTRL) or $50 \mathrm{~g} / \mathrm{d}$ of CLA (CLA) for $10 \mathrm{~d}$. Values represent least squares means, and SEM averaged 0.25 and 42.4 for panels $\mathrm{A}$ and $\mathrm{B}$, respectively.

4). The CLA-induced changes to milk fat and protein variables resulted in an increased $(P<0.01)$ protein:fat ratio of 1.41 vs. 0.75 for $\mathrm{AL}$ and 1.31 vs. 0.65 for $\mathrm{R}$ (Table 3). The CLA infusion increased $(P<0.05)$ milk citrate levels but did not affect the milk urea content (Table 3).

The pasture allowance did not alter the origin (de novo vs. preformed) of milk fatty acids or the content of most individual fatty acids, with the exception of linoleic and linolenic acids, which decreased $(\sim 10 \%$; $P<$ 0.05 ) following pasture restriction (Table 5). Abomasal CLA infusion increased $(P<0.01)$ the milk fat content of trans-8, cis-10; cis-9, trans-11; trans-10, cis-12; cis11, trans-13 CLA, and other unidentified CLA isomers independently of pasture allowance (Table 5). There was also an increase in oleic and linoleic acids following CLA infusion in both R and AL. The CLA infusion decreased the yield (on both a gram and molar basis; data not shown) of all milk fatty acids similarly in both feeding regimes. On a molar basis, de novo-derived fatty acids accounted for $45 \%$ of the decrease, whereas preformed fatty acids and fatty acids containing 16 carbons accounted for 28 and $27 \%$ of the decrease, respectively (data not presented). As a consequence, the fatty acid profile shifted toward a decreased de novo fatty acid content and an increased proportion of preformed fatty acids (Table 5). Based on the myristoleic-to-myristic acid ratio (14:1 to 14:0), neither CLA nor feed restriction altered the $\Delta^{9}$-desaturase system (Table 5).

Calculated EBAL (d 6 to 10 infusion periods) improved following CLA infusion (-0.44 vs. 2.68 and 0.38 vs. $3.29 \mathrm{Mcal} / \mathrm{d}$ for AL and R, respectively; $P<0.01$; Table 3). However, there was no CLA effect on circulating insulin, NEFA, BHBA, urea, or glucose levels (Table 6). Similarly, there was no effect of pasture allowance on measured blood metabolites and hormones (Table 6).

\section{DISCUSSION}

In a pasture-based dairy system, adverse weather conditions can decrease plant growth, plant quality, or both, thus limiting nutrient availability. During these periods, animals can enter into NEBAL, which is associated with a number of metabolic, physiological, and reproductive disorders and often decreases in the yield of milk and milk components (Drackley, 1999; Baumgard et al., 2006). Recently, we and others have demonstrated that a CLA supplement inhibits milk fat synthesis and improves EBAL parameters during other periods when nutrient intake limits production, immediately postpartum (Moore et al., 2004; Shingfield et al., 2004; Kay et al., 2006; Odens et al., 2007), and during heat stress (Moore et al., 2005).

In the present study, the CLA supplement contained $\sim 62 \%$ CLA and provided $17 \mathrm{~g} / \mathrm{d}$ of cis-9, trans-11; trans8, cis-10; and cis-11, trans-13 CLA (isomers that do not alter mammary lipid metabolism; Baumgard et al., 2000; Perfield et al., 2004) and $9 \mathrm{~g} / \mathrm{d}$ of trans-10, cis-12 CLA (a potent inhibitor of milk fat synthesis; Baumgard et al., 2000, 2002). The CLA-induced reductions in milk fat content and yield (Table 3; Figure 1A and 1B) are comparable to previous results in TMR- and pasturefed cows (Chouinard et al., 1999; Mackle et al., 2003; de Veth et al., 2004; Kay et al., 2006). In the present study, MFD (based on milk fat content) became significant by d 2 of infusion (15\%), reached a nadir by d 4 
KAY ET AL.

Table 4. Effect of abomasal infusion of 0 or $50 \mathrm{~g} / \mathrm{d}$ of conjugated linoleic acid (CLA) for $10 \mathrm{~d}$ on milk nitrogen fractions in cows offered ad libitum or restricted pasture ${ }^{1}$

\begin{tabular}{|c|c|c|c|c|c|c|c|c|}
\hline \multirow[b]{2}{*}{ Variable } & \multicolumn{2}{|c|}{$\begin{array}{l}\text { Ad libitum } \\
\text { allowance }\end{array}$} & \multicolumn{2}{|c|}{$\begin{array}{l}\text { Restricted } \\
\text { allowance }\end{array}$} & \multirow[b]{2}{*}{ SEM } & \multicolumn{3}{|c|}{$P^{2}$} \\
\hline & Control & CLA & Control & CLA & & CLA & $\mathrm{A}$ & $\mathrm{CLA} \times \mathrm{A}$ \\
\hline $\mathrm{CP},{ }^{3} \%$ & 3.62 & 3.89 & 3.50 & 3.68 & 0.06 & $<0.01$ & 0.04 & 0.78 \\
\hline True protein, ${ }^{4} \%$ & 3.43 & 3.67 & 3.31 & 3.47 & 0.05 & $<0.01$ & 0.04 & 0.82 \\
\hline $\mathrm{CN},{ }^{5} \%$ & 2.72 & 2.90 & 2.60 & 2.69 & 0.03 & $<0.01$ & 0.04 & 0.98 \\
\hline Whey, ${ }^{6} \%$ & 0.71 & 0.77 & 0.71 & 0.78 & 0.04 & 0.10 & 0.94 & 0.91 \\
\hline $\mathrm{NPN} \times 6.38,{ }^{7} \%$ & 0.19 & 0.22 & 0.19 & 0.21 & 0.01 & 0.02 & 0.69 & 0.26 \\
\hline $\mathrm{NCN} \times 6.38,{ }^{7} \%$ & 0.90 & 0.99 & 0.90 & 0.99 & 0.03 & 0.03 & 0.95 & 0.87 \\
\hline $\mathrm{CN}, \%$ of $\mathrm{TP}$ & 79.30 & 79.01 & 78.49 & 77.52 & 1.00 & 0.37 & 0.34 & 0.82 \\
\hline NPN, \% of TP & 5.54 & 6.00 & 6.06 & 6.05 & 0.28 & 0.43 & 0.46 & 0.24 \\
\hline
\end{tabular}

\footnotetext{
${ }^{1}$ Data represent average from d 9 and 10 of infusion period. Ad libitum allowance: daily pasture allowance of $42 \pm 6.3 \mathrm{~kg} \mathrm{DM} / \mathrm{cow}$. Restricted allowance: daily pasture allowance of $22 \pm 8.5 \mathrm{~kg} \mathrm{DM} / \mathrm{cow}$. Control treatment: abomasal infusion of $0 \mathrm{~g} / \mathrm{d}$ of CLA. CLA treatment: abomasal infusion of $50 \mathrm{~g} / \mathrm{d}$ of CLA.

${ }^{2}$ Significance of effects for CLA dose (CLA), pasture allowance (A), and the interaction between CLA dose and pasture allowance $(\mathrm{CLA} \times \mathrm{A})$.

${ }^{3}$ Crude protein $=$ total nitrogen $(\mathrm{TN}) \times 6.38$.

${ }^{4}$ True protein $(\mathrm{TP})$ calculated as $(\mathrm{TN}-\mathrm{NPN}) \times 6.38$.

${ }^{5} \mathrm{CN}$ protein calculated as $(\mathrm{TN}-\mathrm{NCN}) \times 6.38$.

${ }^{6}$ Whey protein calculated as $(\mathrm{NCN}-\mathrm{NPN}) \times 6.38$.

${ }^{7}$ Multiplied by 6.38 to allow comparison with other protein fractions.
}

(41\%), and returned to preinfusion levels by $5 \mathrm{~d}$ postinfusion (Figure 1A). Additionally, although the CLA infusion decreased the content and yield (data not shown) of fatty acids of all chain lengths, de novo-synthesized fatty acids were reduced to a greater extent than preformed fatty acids, which agrees with pasture- (Mackle et al., 2003; Kay et al., 2006) and TMR-based CLA trials (Perfield et al., 2002; Moore et al., 2005). The fact that we did not detect changes in the $\Delta^{9}$-desaturase system (based on the milk fat 14:1 to 14:0 ratio; Table 5) is surprising, because CLA-induced severe MFD (i.e., greater than $\sim 35 \%$ ) typically reduces the $\Delta^{9}$-desaturase capability, whereas a more moderate CLA-induced MFD (i.e., less than $\sim 20 \%$ ) does not usually affect this ratio (Baumgard et al., 2001; Peterson et al., 2002; de Veth et al., 2004).

The milk fat content of CLA isomers, linoleic and oleic acids, and some trans monoenes increased following CLA infusion, and this reflects the fatty acid composition of the CLA infusate (Table 1) and the effect of CLA on altering the origin of milk fatty acids. Interestingly, the majority of milk fatty acids, and in particular the cis-9, trans-11 CLA content, did not differ between the control, AL, and R treatments (Table 5). Decreased DMI is associated with a decreased rumen passage rate, an increased rumen retention time (Van Soest, 1982), and presumably more extensive biohydrogenation (Allen, 2000). This would presumably decrease the rumen accumulation of fatty acid intermediates, such as trans11 18:1, and consequently decrease substrate availability for mammary synthesis of $c i s-9$, trans-11 CLA via
$\Delta^{9}$-desaturase (Kay et al., 2004). However, based on our data, different pasture allowances and small changes in DMI do not have a large impact on milk fatty acid profiles.

Although most CLA supplementation trials have not detected an increase in either milk yield or component synthesis (Giesy et al., 2002; Perfield et al., 2002), these experiments have typically been conducted while cows are in a positive energy and nutrient balance. Increasing ME availability would not logically enhance milk production if nutrient requirements were already met; however, it may increase production during periods of negative energy and nutrient balance (Baumgard et al., 2006). Fat is the most energetically expensive ( $>50 \%$ of total milk energy) milk component to synthesize (Bauman and Davis, 1974); thus, reducing its production can improve EBAL parameters (Table 3; Moore et al., 2004; Shingfield et al., 2004; Kay et al., 2006; Odens et al., 2007). Based on previous grazing research (Mackle et al., 2003; Back and Lopez-Villalobos, 2004; Kay et al., 2006) indicating that CLA-induced MFD (abomasal infusion or dietary supplementation) increased milk or protein yield or both, we speculated that increased available energy during times of nutrient restriction would be repartitioned toward milk or milk protein synthesis, or both. Research suggests that spared energy (via CLA-induced MFD) has a more profound effect on milk production in grazing cows than in cows fed a more energy-dense TMR (a diet that might better match energy and other nutrient requirements; Mackle et al., 2003). As hypothesized, data from the 
Table 5. Effect of abomasal infusion of 0 or $50 \mathrm{~g} / \mathrm{d}$ of conjugated linoleic acid (CLA) for $10 \mathrm{~d}$ on milk fatty acids in cows offered ad libitum or restricted pasture ${ }^{1}$

\begin{tabular}{|c|c|c|c|c|c|c|c|c|}
\hline \multirow[b]{2}{*}{ Fatty acid } & \multicolumn{2}{|c|}{ Ad libitum allowance } & \multicolumn{2}{|c|}{ Restricted allowance } & \multirow[b]{2}{*}{ SEM } & \multicolumn{3}{|c|}{$P^{2}$} \\
\hline & Control & CLA & Control & CLA & & CLA & $\mathrm{A}$ & $\mathrm{CLA} \times \mathrm{A}$ \\
\hline & \multicolumn{4}{|c|}{ (mg/g of total fatty acids) } & & & & \\
\hline $4: 0$ & 29.72 & 17.91 & 26.44 & 16.90 & 1.31 & $<0.01$ & 0.13 & 0.41 \\
\hline $6: 0$ & 18.53 & 8.94 & 17.19 & 8.84 & 0.77 & $<0.01$ & 0.37 & 0.43 \\
\hline 8:0 & 10.45 & 4.40 & 9.65 & 4.52 & 0.49 & $<0.01$ & 0.50 & 0.67 \\
\hline $10: 0$ & 23.15 & 11.05 & 21.92 & 11.32 & 1.01 & $<0.01$ & 0.65 & 0.47 \\
\hline $10: 1$ & 2.49 & 0.86 & 2.14 & 0.74 & 0.21 & $<0.01$ & 0.28 & 0.59 \\
\hline $12: 0$ & 27.00 & 17.07 & 25.32 & 17.58 & 1.19 & $<0.01$ & 0.63 & 0.37 \\
\hline $14: 0$ & 94.22 & 84.41 & 91.94 & 86.95 & 2.80 & 0.02 & 0.96 & 0.40 \\
\hline $14: 1 c 9$ & 6.88 & 7.74 & 6.31 & 6.23 & 0.80 & 0.63 & 0.22 & 0.57 \\
\hline $15: 0$ & 14.52 & 14.66 & 15.01 & 15.78 & 0.45 & 0.33 & 0.09 & 0.49 \\
\hline $16: 0$ & 265.07 & 263.05 & 270.60 & 263.57 & 8.79 & 0.61 & 0.74 & 0.78 \\
\hline $16: 1 c 9$ & 16.55 & 20.47 & 19.23 & 21.33 & 1.49 & 0.61 & 0.25 & 0.55 \\
\hline $17: 0$ & 7.17 & 7.83 & 7.58 & 8.42 & 0.26 & 0.01 & 0.07 & 0.75 \\
\hline $17: 1$ & 2.93 & 3.40 & 3.42 & 3.34 & 0.19 & 0.33 & 0.29 & 0.18 \\
\hline 18:0 & 106.12 & 117.15 & 105.35 & 120.15 & 6.87 & 0.08 & 0.87 & 0.79 \\
\hline $18: 1 c 9$ & 183.57 & 204.23 & 192.48 & 207.77 & 6.09 & $<0.01$ & 0.08 & 0.23 \\
\hline $18: 1 t 6-8$ & 0.95 & 1.42 & 0.82 & 1.05 & 0.17 & 0.06 & 0.17 & 0.50 \\
\hline 18:1 t9 & 4.78 & 5.25 & 4.05 & 4.79 & 0.26 & 0.04 & 0.04 & 0.61 \\
\hline $18: 1 t 10$ & 4.67 & 5.52 & 4.30 & 4.24 & 0.24 & 0.47 & 0.20 & 0.45 \\
\hline 18:1 $t 11$ & 41.62 & 41.87 & 41.92 & 45.89 & 2.24 & 0.36 & 0.35 & 0.42 \\
\hline $18: 1 t 12$ & 4.10 & 4.08 & 2.95 & 3.21 & 0.26 & 0.64 & $<0.01$ & 0.60 \\
\hline Total $t 18: 1$ & 56.12 & 58.14 & 54.04 & 59.18 & 3.32 & 0.25 & 0.55 & 0.21 \\
\hline $18: 2 c 9, c 12$ & 12.82 & 17.03 & 11.73 & 15.02 & 0.47 & $<0.01$ & 0.01 & 0.34 \\
\hline CLA $t 8, c 10$ & 0.35 & 0.66 & 0.25 & 0.63 & 0.02 & $<0.01$ & $<0.01$ & 0.08 \\
\hline CLA $c 9, t 11$ & 18.72 & 23.18 & 18.45 & 24.16 & 0.97 & $<0.01$ & 0.72 & 0.53 \\
\hline CLA $t 10, c 12$ & 0.98 & 6.43 & 0.90 & 7.35 & 0.22 & $<0.01$ & 0.08 & 0.06 \\
\hline CLA $c 11, t 13$ & 1.87 & 2.53 & 1.57 & 2.59 & 0.16 & $<0.01$ & 0.44 & 0.28 \\
\hline Other CLA & 1.13 & 1.56 & 1.10 & 1.62 & 0.04 & $<0.01$ & 0.44 & 0.03 \\
\hline $18: 3 c 9, c 12, c 15$ & 10.45 & 11.75 & 9.75 & 10.02 & 0.59 & 0.20 & 0.05 & 0.39 \\
\hline $20: 0$ & 0.82 & 0.84 & 0.79 & 0.86 & 0.12 & 0.65 & 0.82 & 0.47 \\
\hline Unknown $^{3}$ & 75.06 & 74.79 & 74.69 & 64.85 & 2.78 & 0.69 & 0.48 & 0.32 \\
\hline \multicolumn{9}{|l|}{ Fatty acid origin } \\
\hline De novo 4 & 226.96 & 167.04 & 215.92 & 168.87 & 7.33 & $<0.01$ & 0.54 & 0.39 \\
\hline $16: 0$ and $16: 1$ & 281.62 & 283.52 & 289.83 & 284.90 & 9.20 & 0.87 & 0.61 & 0.72 \\
\hline Preformed $^{5}$ & 409.73 & 472.38 & 417.73 & 473.69 & 10.85 & $<0.01$ & 0.67 & 0.76 \\
\hline $14: 1 / 14: 0$ & 7.17 & 9.00 & 7.00 & 7.54 & 0.85 & 0.18 & 0.35 & 0.46 \\
\hline
\end{tabular}

${ }^{1}$ Data represent the average from d 9 and 10 of the infusion period. Ad libitum allowance: daily pasture allowance of $42 \pm 6.3 \mathrm{~kg}$ of DM/cow. Restricted allowance: daily pasture allowance of $22 \pm 8.5 \mathrm{~kg}$ of DM/ cow. Control treatment: abomasal infusion of $0 \mathrm{~g} / \mathrm{d}$ of CLA. CLA treatment: abomasal infusion of $50 \mathrm{~g} / \mathrm{d}$ of CLA.

${ }^{2}$ Significance of effects for CLA infusion (CLA), pasture allowance (A), and the interaction between CLA infusion and pasture allowance $(\mathrm{CLA} \times \mathrm{A})$.

${ }^{3}$ Represents unidentified chromatograph peaks.

${ }^{4}$ Sum of $4: 0$ to $15: 0$.

${ }^{5}$ Sum of $17: 0$ to $20: 0$.

present study demonstrated a CLA-induced increase in protein synthesis; however, in contrast to previous reports (Mackle et al., 2003; Back and Lopez-Villalobos, 2004; Kay et al., 2006), the CLA-induced increase in the current study was due to an increased protein content and not an increased milk yield, as reported in the aforementioned studies.

In the present study, the lack of increase in milk yield in restricted pasture may possibly be due to the extent of CLA-induced MFD. We have recently reported a curvilinear relationship between the severity of MFD and the increase in milk yield immediately postpartum.
Cows supplemented with CLA tended to produce more milk when MFD was moderate (less than $~ 35 \%$ ); however, as MFD became more severe, the positive milk yield response was eliminated (Kay et al., 2006). This supports our earlier work indicating a quadratic milk yield response with increasing CLA doses (Mackle et al., 2003). In addition, both Chouinard et al. (1999) and Bell and Kennelly (2003) reported reduced milk yield (15 and 40\%, respectively), when a high CLA dose was abomasally infused. These trials suggest that during times of energy deficiency (i.e., immediately postpartum or in grazing situations), moderate inhibition of 
Table 6. Effect of abomasal infusion of 0 or $50 \mathrm{~g} / \mathrm{d}$ of conjugated linoleic acid (CLA) for $10 \mathrm{~d}$ on plasma hormones and metabolites in cows offered grazing ad libitum or restricted pasture ${ }^{1}$

\begin{tabular}{|c|c|c|c|c|c|c|c|c|}
\hline \multirow[b]{2}{*}{ Variable } & \multicolumn{2}{|c|}{$\begin{array}{l}\text { Ad libitum } \\
\text { allowance }\end{array}$} & \multicolumn{2}{|c|}{$\begin{array}{l}\text { Restricted } \\
\text { allowance }\end{array}$} & \multirow[b]{2}{*}{ SEM } & \multicolumn{3}{|c|}{$P^{2}$} \\
\hline & Control & CLA & Control & CLA & & CLA & A & $\mathrm{CLA} \times \mathrm{A}$ \\
\hline Insulin, ng/mL & 0.31 & 0.33 & 0.29 & 0.31 & 0.03 & 0.63 & 0.61 & 0.91 \\
\hline NEFA, mM & 0.12 & 0.12 & 0.18 & 0.14 & 0.02 & 0.42 & 0.10 & 0.33 \\
\hline BHBA, $\mathrm{m} M$ & 0.62 & 0.57 & 0.58 & 0.55 & 0.09 & 0.63 & 0.77 & 0.92 \\
\hline Urea, $\mathrm{m} M$ & 7.23 & 6.95 & 7.11 & 7.13 & 0.32 & 0.69 & 0.93 & 0.64 \\
\hline Glucose, $\mathrm{m} M$ & 2.73 & 2.78 & 2.63 & 2.63 & 0.26 & 0.95 & 0.63 & 0.92 \\
\hline
\end{tabular}

${ }^{1}$ Data represent average from d 9 and 10 of infusion period. Ad libitum allowance: daily pasture allowance of $42 \pm 6.3 \mathrm{~kg}$ of $\mathrm{DM} / \mathrm{cow}$. Restricted allowance: daily pasture allowance of $22 \pm 8.5 \mathrm{~kg} \mathrm{DM} / \mathrm{cow}$. Control treatment: abomasal infusion of $0 \mathrm{~g} / \mathrm{d}$ CLA. CLA treatment: abomasal infusion of $50 \mathrm{~g} / \mathrm{d}$ CLA.

${ }^{2}$ Significance of effects for CLA infusion (CLA), pasture allowance (A), and the interaction between CLA infusion and pasture allowance $(\mathrm{CLA} \times \mathrm{A})$.

milk fat synthesis may spare energy that is then partitioned for increased milk yield. However, severe CLAinduced MFD may sometimes adversely affect cellular mechanisms involved in milk synthesis, milk secretion, or both. Severe CLA-induced MFD (i.e., $>35$ to 40\%) does not always adversely affect milk yield (Baumgard et al., 2001; Dohme et al., 2004; Shingfield et al., 2004), and the reasons for the inconsistencies are unknown but may include 1) the dose and duration of CLA infusion or feeding, 2) CLA composition differences, 3) variations in the pre-CLA treatment milk yield, 4) differences in basal diets, and 5) differences in the cows' energetic and physiological states. Further research is required to examine the relationship between the magnitude of CLA-induced MFD and the milk yield response.

Alternatively, the lack of a positive milk yield response in the current trial may be due to limitations in the ability of this particular model to mimic energy or nutrient deprivation. During times of nutrient inadequacy, homeorheteric mechanisms alter tissue metabolism in an attempt to maintain milk production; consequently, the animal enters into NEBAL. These coordinated changes include increased lipolysis and decreased extramammary glucose uptake and utilization (Bauman and Currie, 1980) and result in increased plasma NEFA and BHBA and in decreased circulating glucose and insulin levels. In the present study, however, DMI decreased by only $\sim 1.5 \mathrm{~kg}$ of $\mathrm{DM} / \mathrm{d}$ with the $\mathrm{R}$ treatment, and neither EBAL nor plasma hormones and metabolites were affected by pasture allowance. The reason we did not observe changes in EBAL parameters as we expected is probably because the large decrease $(25 \%)$ in milk yield with pasture restriction (Table 3 ) caused cows to subsequently remain in calculated positive EBAL (Table 3). The lack of CLA-induced changes in bioenergetic variables (Table 6) is consistent with our previous research evaluating homeostatic pa- rameters (both basal and stimulated) from cows in positive EBAL (Baumgard et al., 2002). Therefore, nutrient deprivation in the present study may not have been extensive enough to detect or measure milk yield and bioenergetic improvements because of increased available energy. Additionally, it is noteworthy that a supplemental CLA dose high enough to evoke severe MFD $(\sim 45 \%)$ did not have any apparent adverse affects on metabolism or animal health.

Although milk yield was not affected by CLA in the present experiment, the increase in milk protein and decrease in milk fat yield resulted in a doubling of the milk protein:fat ratio. Based on the global trend for weighted milk payment schemes, which places a premium on milk protein, this improved component ratio could potentially increase milk value. The increased $\mathrm{CN}$ and trend for increased whey content (Table 4) suggest that CLA-induced MFD may enhance the energy available for de novo mammary protein synthesis. Increased pasture allowance in the ad libitum treatment also resulted in increased milk protein content, which agrees with previous research using similar pasture allowances (O'Brien et al., 1997; Mackle et al., 1999; Auldist et al., 2000) and is most probably due to increased energy intake sparing AA from gluconeogenesis, thus increasing the AA supply for milk protein synthesis.

The milk citrate content increased with CLA infusion, which confirms our previous report indicating a linear increase with an increasing dose of CLA (Mackle et al., 2003). Citrate is central to mammary cell metabolism and provides reducing equivalents (NADPH) for fatty acid synthesis via the isocitrate dehydrogenase pathway (Bauman and Davis, 1974). Faulkner and Peaker (1982) postulated that a decrease in de novo fatty acid synthesis would reduce cystolic NADPH utilization and, as a consequence, the isocitrate cycle (for $\mathrm{NADPH}$ production) would be reduced, resulting in in- 
creased cytoplasmic citrate concentrations. Consistent with this hypothesis, Mackle et al. (2003) and the current data (Table 3) indicate that CLA-induced MFD results in increased milk citrate levels.

In summary, data from the present study demonstrate that abomasal CLA infusion inhibits milk fat synthesis to the same extent in cows fed ad libitum or nutrient restricted. Conjugated linoleic acid-induced MFD increased the calculated EBAL in both AL and R treatments, and some of the available energy appeared to be partitioned toward milk protein synthesis. Milk yield decreased with pasture restriction and did not improve with the CLA treatment as hypothesized. The lack of a positive CLA-induced milk yield response may be associated with the severe reduction in milk fat synthesis (greater than $\sim 35 \%$ ) or potential current model limitations. Further research, using a model with a lower CLA dose combined with a more severe nutrient restriction, may determine whether CLA could potentially alleviate NEBAL and improve production and bioenergetic parameters during periods of feed shortage.

\section{REFERENCES}

Allen, M. S. 2000. Effects of diet on short-term regulation of feed intake by lactating dairy cattle. J. Dairy Sci. 83:1598-1624.

AOAC. 2000. Official Methods of Analysis. 17th ed. AOAC, Arlington, VA.

Auldist, M. J., N. A. Thomson, T. R. Mackle, J. P. Hill, and C. G. Prosser. 2000. Effects of pasture allowance on the yield and composition of milk from cows of different $\beta$-lactoglobulin phenotypes. J. Dairy Sci. 83:2069-2074.

Back, P. J., and N. Lopez-Villalobos. 2004. Effects of a commercial feed containing conjugated linoleic acid on the production of milk components and the value of milk. Proc. N. Z. Soc. Anim. Prod. 64:150-154.

Bauman, D. E., and W. B. Currie. 1980. Partitioning of nutrients during pregnancy and lactation: A review of mechanisms involving homeostasis and homeorhesis. J. Dairy Sci. 63:1514-1529.

Bauman, D. E., and C. L. Davis. 1974. Biosynthesis of milk fat. Pages 31-75 in Lactation: A Comprehensive Treatise. B. L. Larson, ed. Academic Press, New York, NY.

Baumgard, L. H., B. A. Corl, D. A. Dwyer, and D. E. Bauman. 2002. Effects of conjugated linoleic acid (CLA) on lipid metabolism of lactating dairy cows. J. Anim. Sci. 80:1285-1293.

Baumgard, L. H., B. A. Corl, D. A. Dwyer, A. Saebo, and D. E. Bauman. 2000. Identification of the conjugated linoleic acid isomer that inhibits milk fat synthesis. Am. J. Physiol. 278:R179-R184.

Baumgard, L. H., L. J. Odens, J. K. Kay, R. P. Rhoads, M. J. VanBaale, and R. J. Collier. 2006. Does negative energy balance (NEBAL) limit milk synthesis in early lactation? Pages 181-187 in Proc. Southwest Nutr. Conf. http://animal.cals.arizona.edu/swnmc/ 2006/proceedings.php Accessed March 1, 2006.

Baumgard, L. H., J. K. Sangster, and D. E. Bauman. 2001. Milk fat synthesis in dairy cows is progressively reduced by increasing supplemental amounts of trans-10, cis-12 conjugated linoleic acid (CLA). J. Nutr. 131:1764-1769.

Bell, J. A., and J. J. Kennelly. 2003. Short communication: Postruminal infusion of conjugated linoleic acid negatively impacts milk synthesis in Holstein cows. J. Dairy Sci. 86:1321-1324.

Chouinard, P. Y., L. Corneau, D. M. Barbano, L. E. Mettzger, and D. E. Bauman. 1999. Conjugated linoleic acids alter milk fatty acid composition and inhibit milk fat secretion in dairy cows. J. Nutr. 129:1579-1584.

Collier, R. J., L. H. Baumgard, A. L. Lock, and D. E. Bauman. 2005. Physiological limitations, nutrient partitioning. Pages 351-377 in Yields of Farmed Species: Constraints and Opportunities in the 21st Century. Proc. 61st Easter School, Nottingham, UK. J. Wiseman, and R. Bradley, ed. Nottingham University Press, Nottingham, UK.

Corson, D. G., G. C. Waghorn, M. J. Ulyatt, and J. Lee. 1999. Forage analysis and livestock feeding. Proc. N. Z. Grasslands Assoc. 61:127-132.

Dagley, S. 1974. Citrate: UV spectrophotometric determination. Pages 1562-1569 in Methods of Enzymatic Analysis. 2nd ed. H. Bergmeyer, ed. Verlag Chemie, Weinheim, Germany.

de Veth, M. J., J. M. Griinari, A. M. Pfeiffer, and D. E. Bauman. 2004. Effect of CLA on milk fat synthesis in dairy cows: Comparison of inhibition by methyl esters and free fatty acids, and relationships among studies. Lipids 39:365-372.

Dohme, F., M. Collomb, and G. Bee. 2004. Comparison of CLA methyl esters and sunflower seeds in their effects on milk fat content and fatty acid profile in cows. Proc. Soc. Nutr. Physiol. 13:72(Abstr.).

Dowman, M., and F. Collins. 1982. The use of enzymes to predict the digestibility of animal feeds. J. Sci. Food Agric. 33:689-696.

Drackley, J. K. 1999. Biology of dairy cows during the transition period: The final frontier? J. Dairy Sci. 82:2259-2273.

Faulkner, A., and M. Peaker. 1982. Reviews of the progress of dairy science: Secretion of citrate into milk. J. Dairy Res. 49:159-169.

Garces, R., and M. Mancha. 1993. One-step lipid extraction and fatty acid methyl esters preparation from fresh plant tissues. Anal. Biochem. 211:139-143.

Giesy, J. G., M. A. McGuire, B. Shafii, and T. W. Hanson. 2002. Effect of dose of calcium salts of conjugated linoleic acid (CLA) on percentage and fatty acid content of milk fat in midlactation Holstein cows. J. Dairy Sci. 85:2023-2029.

Hales, C. N., and P. J. Randle. 1963. Immunoassay of insulin with insulin-antibody precipitate. J. Biochem. (Tokyo) 88:137-146.

Holmes, C. W., I. M. Brookes, D. J. Garrick, D. D. S. Mackenzie, T. J. Parkinson, and G. F. Wilson. 2002. Nutrition: Quantitative requirements for dairy cattle. Pages 235-262 in Milk Production from Pasture. Massy Univ. Press, Palmerston North, New Zealand.

IDF (International Dairy Federation). 1964. Determination of the casein content of milk. IDF Bull. No. 29. Int. Dairy Fed., Brussels, Belgium.

Kay, J. K., T. R. Mackle, M. J. Auldist, N. A. Thomson, and D. E. Bauman. 2004. Endogenous synthesis of cis-9, trans-11 conjugated linoleic acid in dairy cows fed fresh pasture. J. Dairy Sci. 87:369-378.

Kay, J. K., J. R. Roche, C. E. Moore, and L. H. Baumgard. 2006. Effects of dietary conjugated linoleic acid on production and metabolic parameters in transition dairy cows grazing fresh pasture. J. Dairy Res. 73:367-377.

Loor, J. J., and J. H. Herbein. 1998. Exogenous conjugated linoleic acid isomers reduce bovine milk fat concentration and yield by inhibiting de novo fatty acids synthesis. J. Nutr. 128:2411-2419.

MacGibbon, A. K. H. 1988. Modified method of fat extraction for solid fat content determination. N. Z. J. Dairy Sci. Technol. 23:399-403.

Mackle, T. R., A. M. Bryant, S. F. Petch, J. P. Hill, and M. J. Auldist. 1999. Nutritional influences on the composition of milk from cows of different protein phenotypes in New Zealand. J. Dairy Sci. 82:172-180.

Mackle, T. R., J. K. Kay, M. J. Auldist, A. K. H. MacGibbon, B. A. Philpott, L. H. Baumgard, and D. E. Bauman. 2003. Effects of abomasal infusion of conjugated linoleic acid on milk fat concentration and yield from pasture-fed dairy cows. J. Dairy Sci. 86:644-652.

Mayes, R. W., C. S. Lamb, and P. M. Colgrove. 1986. The use of dosed and herbage $n$-alkanes as markers for the determination of herbage intake. J. Agric. Sci. (Camb.) 107:161-170.

Moore, C. E., H. C. Hafliger, III, O. B. Mendivil, S. R. Sanders, D. E. Bauman, and L. H. Baumgard. 2004. Increasing amounts of 
conjugated linoleic acid (CLA) progressively reduce milk fat synthesis immediately postpartum. J. Dairy Sci. 87:1886-1895.

Moore, C. E., J. K. Kay, R. J. Collier, M. J. VanBaale, and L. H. Baumgard. 2005. Effect of supplemental conjugated linoleic acid on heat stressed Brown Swiss and Holstein cows. J. Dairy Sci. 88:1732-1740.

NRC. 2001. Nutrient Requirements of Dairy Cattle. 7th rev. ed. National Academy Press, Washington, DC.

O’Brien, B. J., J. J. Murphy, J. F. Connolly, R. Mehra, T. P. Guinee, and G. Stakelum. 1997. Effect of altering the daily herbage allowance in mid-lactation on the composition and processing characteristics of bovine milk. J. Dairy Res. 64:621-626.

Odens, L. J., R. Burgos, M. Innocente, M. J. VanBaale, and L. H. Baumgard. 2007. Effects of varying doses of supplemental CLA on production and energetic variables during the transition period. J. Dairy Sci. 90:293-305.

Perfield, J. W., II, G. Bernal-Santos, T. R. Overton, and D. E. Bauman. 2002. Effects of dietary supplementation of rumen-inert conjugated linoleic acid in dairy cows during established lactation. J. Dairy Sci. 85:2609-2617.

Perfield, J. W., II, A. Sæbø, and D. E. Bauman. 2004. Use of conjugated linoleic acid (CLA) enrichments to examine the effects of trans-
8, cis-10 CLA, and cis-11, trans-13 CLA on milk-fat synthesis. J. Dairy Sci. 87:1196-1202.

Peterson, D. G., L. H. Baumgard, and D. E. Bauman. 2002. Short communication: Milk fat response to low doses of trans-10, cis12 conjugated linoleic acid (CLA). J. Dairy Sci. 85:1764-1766.

Roche, J. R., S. Petch, and J. K. Kay. 2005. Manipulating the dietary cation-anion difference via drenching to early lactating dairy cows grazing pasture. J. Dairy Sci. 88:264-276.

Roughan, G. P., and R. Hollan. 1977. Predicting in-vivo digestibilities of herbage by exhaustive enzymatic hydrolysis of cell walls. J. Sci. Food Agric. 28:1057-1064.

SAS Institute. 2001. SAS/STATS User's Guide, Version 8.0. SAS Inst., Inc., Cary, NC.

Shingfield, K. J., D. E. Beever, C. K. Reynolds, S. K. Gulati, D. J. Humphries, B. Lupoli, G. Hervas, and M. J. Griinari. 2004. Effect of rumen protected conjugated linoleic acid on energy metabolism of dairy cows during early to mid-lactation. J. Dairy Sci. 87(Suppl. 1):307. (Abstr.)

Talke, H., and G. E. Schubert. 1965. Enzymatic urea determination in the blood and serum in the Warburg optical test. Klin. Wochenschr. 43:174-175.

Van Soest, P. J. 1982. Lipids. Pages 325-336 in Nutritional Ecology of the Ruminant. P. J. Van Soest, ed. O \& B Books, Corvallis, OR. 